\title{
PERAN MATA KULIAH PENDIDIKAN PANCASILA SEBAGAI MATA KULIAH WAJIB UMUM DALAM MENGEMBANGKAN KEPRIBADIAN MAHASISWA YANG SESUAI DENGAN NILAI- NILAI PANCASILA
}

\author{
Febrian Alwan Bahrudin ${ }^{1}$ \\ Dosen Program Studi PPKn FKIP Universitas Sultan Ageng Tirtayasa \\ Serang, Indonesia \\ febrian_alwan24@yahoo.com
}

\begin{abstract}
This research was conducted to know the role of Pancasila education subject as general compulsory subject in developing students 'personality based on Pancasila values. The background of this research was related to the problems which happened in this country: anarchism, radicalism, terrorism, and other problems those could be able to damage the unity and integrity of the republic of Indonesia. Therefore, Pancasila education subject must be implemented in a university, this is in accordance with Law No. 12 of 2012, article 35 paragraph 3. The place of this research was at Sultan Ageng Tirtayasa University. This research used qualitative approach and descriptive method. The results of this research shown that Pancasila education subject at Sultan Ageng Tirtayasa University had a very important role in developing students personality in accordance with the values of Pancasila, this could be seen in learning achievements: cognitive, psychomotor, affective. In the achievement of cognitive, the students were taught some materials related to the semester learning plan, with the aim was to make students having knowledge of Pancasila, the achievement of psychomotor emphasized to students` skills by using learning methods as a form of student centered learning. In affective achievement could be seen in the students personality which had been in accordance with the values of Pancasila.
\end{abstract}

Keywords: The Role of Pancasila Education.

\section{PENDAHULUAN}

Negara Indonesia merupakan negara yang begitu luas, dengan luas $1,905 \mathrm{~km}^{2}$, dan penduduknya begitu banyak, dengan jumlah penduduk 264 juta jiwa. berdasarkan luas dan jumlah penduduk yang begitu banyak diperlukan sesuatu yang dapat menyatukan semuanya itu, sesuatu yang kuat, sesuatu yang tidak termakan oleh zaman, dan untuk menyatukan semuanya itu yaitu melalui Pancasila, peran dari Pancasila sendiri sangatlah penting, karena negara Indonesia ini sangatlah kaya akan keaneragaman baik suku bangsa, bahasa, agama, seni, budaya, dll, keaneragaman tersebut apabila tidak ada yang dapat menyatukan maka tidak akan ada negara Indonesia yang bersatu sampai saat ini, perjalanan negara Indonesia yang telah merdeka sampai saat ini selama 74 tahun tidak lapas dari permasalahan-permasalahan yang melanda di negara ini, mulai dari anarkisme, radikalisme, terorisme, dan permasalahan-permasalahan lainnya di negara ini yang dapat memecah belah persatuan dan kesatuan negara rebublik Indonesia, anarkisme yang terjadi di negara 
ini yaitu masih terdapat beberapa masyarakat atau sekolompok masyarakat yang cenderung melakukan aksinya melalui kekerasan sebagai bentuk anarkisme tersebut, radikalisme yang terjadi di negara ini yaitu melui pemahaman tentang keinginan untuk mengganti dasar dan ideologi negara dengan melawan ketentuan atauran yang berlaku di negara Indonesia ini, dan terorisme yang terjadi di negara ini merupakan aksi kekerasan ataupun ancaman yang dapat menimbulkan ketakutan hingga korban jiwa yang telah terjadi beberapa kali di negara ini, kesemuanya itu bertujuan memecah belah persatuan dan kesatuan negara Indonesia ini, maka peran Pancasila sangatlah penting untuk keberlangsungan negara Indonesia ini, peran Pancasila sebagai pemersatu bangsa harus dapat difahamai dan diimplementasikan oleh suluruh masyarakat Indonesia sebagai pemersatu bangsa.

Pancasila sebagai dasar dan ideologi negara harus dapat difahami dan diimplementasikan disemua lapisan masyarakat, pemahaman dan implementasi tersebut bertujuan untuk dapat mempersatukan bangsa ini sehingga tidak akan bercerai-berai, pemahaman dan implementasi tentang Pancasila itu sendiri salah satunya melalui jalur pendidikan, khusnya malalui jalur pendidikan formal, hal ini sebagaimana yang terdapat dalam Undang-Undang Nomor 20 tahun 2003 tentang sistem pendidikan nasional pasal 37 yang menyatakan bahwa:

"Pendidikan Pancasila dan Kewarganegaraan yaitu merupakan bagian dari mata pelajaran atau mata kuliah yang wajib ada dalam kurikulum baik dalam pendidikan dasar, pendidikan menengah dan pendidikan tinggi, Pendidikan Pancasila dan Kewarganegaraan ini merupakan suatu program kurikulum yang dirancang kedalam kurikum formal, berdasarkan hasil dari pemikiran para ahli, pelaksanaannya sendiri disesuaikan dengan rentang usia, dan tingkatan jenjang pendidikan, dengan tujuan mengarah terhadap pembangunan karakter bangsa warga negara". Berdasarkan hal tersebut bahwasanya mata pelajaran atau mata kuliah Pendidikan Pancasila dan Kewarganegaraan merupakan pembelajaran yang harus diajarkan dalam ruang lingkup pendidikan formal, pendidikan formal di Indonesia sendiri merupakan suatu pendidikan yang dilaksanakan di sekolah, dalam pendidikan formal memiliki jenjang pendidikan yaitu jenjang pendidikan dasar, jenjang pendidikan menengah, dan jenjang pendidikan tinggi, keharusan atau kewajiban melaksanakan pendidikan Pancasila disemua jenjang pendidikan tersebut merupakan bagian pembelajaran bagi peserta didik dengan cara internalisasi, institusionlisasi nilai-nilai Pancasila dan sistematik terhadap peserta didik itu sendiri dari jenjang pendidikan 
dasar sampai dengan pendidikan tinggi, tetapi keadaan saat ini dalam pelaksanaan pembelajaran pendidikan Pancasila sendiri masih banyak yang mengarah pada sasaran aspek kompetensi kognitif itu sendiri dibandingkan dengan aspek kompetensi lainnya seperti afektif dan psikomotor, sehingga banyak anggapan pembelajaran pendidikan Pancasila hanya sebatas teori atau sebatas menghafal dan memahami saja, justru seharusnya pembelajaran pendidikan Pancasila haruslah menyeluruh baik sasaran kompentensi kognitif, afektif dan psiskomotor sehingga dapat diimplemtasikan bukan hanya sebatas teori semata tetapi harus sampai pada tahap peimplementasian nilainilai yang ada dalam Pancasila itu sendiri yang harus melekat dalam diri siswa atau mahasiswa. Pelaksanaan pendidikan Pancasila disemua jejang pendidikan formal, baik jenjang pendidikan dasar dan pendidikan tinggi haruslah merubah proses pembelajaran yang banyak orang menganggap bahwa mata pelajaran atau mata kuliah pendidikan Pancasila merupakan sebatas hafalan semata. Jenjang pendidikan formal seharusnya dapat dijadikan sebagai sarana penguatan nilai-nilai Pancasila dalam diri siswa atau mahasiswa itu sendiri, salah satu jenjang yang terdapat dalam pendidikan formal yaitu jenjang pendidikan tinggi yang terdiri dari Diploma, sarjana, megister, doktor dan spesialis, kesemuanya itu dilaksanakan di perguruan tinggi. setiap perguruan tinggi memilki kurikulum untuk mencapai sasaran kompetensinya, kurikulum yang ada di perguruan tinggi pada tingkat diploma dan sarjana tersebut haruslah memuat mata kuliah wajib salah satunya adalah mata kuliah Pendidikan Pancasila, hal ini sebagaimana terdapat dalam edaran Dirjen Dikti No 914/E/T/2011 tentang penyelenggaraan perkuliahan Pendidikan Pancasila di Perguruan tinggi, berdasarkan edaran Dirjen Dikti tersebut "penyelenggaran pendidikan Pancasila diperguruan tinggi haruslah dilaksanakan yaitu dengan bobot minimal 2 sks, dan dalam pelaksanaan atau proses perkuliahan mengutamakan terhadap peningkatan pembelajaran yang bersifat konstektual dan dalam proses pembelajaran atau perkuliahan haruslah inovatif, kreatif, dan juga menggunakan sistem evaluasi pembelajaran yang sesuai, selaian itu perguruaan tinggi haruslah melaksanakan kajian-kajian tentang Pancasila yang bertujuan untuk dapat membudayakan nilainilai Pancasila dan dapat mengimplementasikan didalam ketentuan atau peraturan yang berlaku sebagai bentuk suasana akademis yang sesuai dengan nilainilai Pancasila". Selain edaran Dirjen Dikti tentang mata kuiah Pendidikan Pancasila hal lain yang menekankan akan kharusan menyelenggarakan mata kuliah Pendidikan Pancasila sebagai salah satu mata kuliah 
wajib diantara mata kuliah Pendidikan Kewarganegaraan, mata kuliah Pendidikan Bahasa Indonesia dan mata kuliah Pendidikan Agama, mata kuliah-mata kuliah tersebut harus dapat dilaksanakan di perguruan tinggi pada tinggkat diploma dan sarjana, hal ini sebagaimana terdapat dalam Undang-Undang No 12 Tahun 2012, pasal 35 ayat 3. Tentang pendidikan tinggi yang sekaligus mengacu pada Permenristekdikti No 44 tahun 2015 menyatakan bahwa “...Pendidikan tinggi wajib memuat mata kuliah pendidikan Agama, pendidikan Pancasila, pendidikan Kewarganegaraan dan Juga Pendidikan Bahasa Indonesia". berdasarkan hal tersebut dalam peraturan Undang-Undang di atas memisahkan antara mata kuliah Pendidikan Pancasila dan Mata kuliah Pendidikan Kewarganegaraan yang awalnya pada peraturan Dirjen Dikti No 914/E/T/2011 yang memperbolehkan untuk memisahkan atau juga menggabungkan menjadi mata kuliah Pendidikan Pancasila dan Kewarganegaraan yang memilki bobot sks sebesar 3 sks, tetapi dalam UndangUndang No 12 Tahun 2012, Pasal 35 ayat 3 ini menyatakan bahwa: "Pelaksanaan mata kuliah pendidikan Pancasila harus atau wajib dilaksanakan secara mandiri disemua perguruan tinggi yaitu dijenjang diploma dan sarjana, dengan memiliki visi, misi dan juga tujuan, hal ini dimaksudkan supaya tidak terjadi tumpang tindih antara mata kuliah
Pendidikan Pancasila dengan mata kuliah Pendidikan Kewarganegaraan, tetapi diantara kedua mata kuliah tersebut tetaplah memilki hubungan keterkaitan antara satu sama lain”. berdasarkan hal indikator tersebut bahwa Pendidikan Pancasila memilki peranan yang sangat penting untuk menjadikan pondasi yang kuat dalam ruang likup pendidikan tinggi di negara Indonesia ini. selain itu diwajibkannya mata kuliah di atas adalah untuk dapat menjadikan mahasiswa yang berkarakter tangguh, cinta tanah air, memilki jiwa bela negara, memilki jati diri bangsa yang kuat, sekaligus membentuk budaya bangsa terhadap diri mahasiswa, peran mahasiswa sebagai penerus generasi bangsa haruslah memilki nilai-nilai Pancasila dalam dirinya sebagai upaya pembentukan karakter bangsa yang sesuai dengan nilai-nilai Pancasila, sehingga tidak akan mudah terpapar hal-hal negatif seperti anarkisme, radikalisme, terorisme dan hal-hal negatif lainnya yang dapat memecah belah kedaulatan negara republik Indonesia. Mahasiswa perlu memahami akan pentingnya Pancasila itu sendiri, karena mahasiswa merupakan individu yang memilki nilai intelektualitas yang tingggi yang dapat membedakan mana yang baik dan yang buruk tentang bagaimana berwarganegara di Indonesia ini, hal ini sebagaimana dikemukan oleh : "Siswoyo (2007:121) "mahasiswa dapat didefenisikan sebagai seseorang atau 
individu yang menempuh pendidikan disuatu perguruan tinggi, dan mahasiswa memilki penilaian dari masyarakat sebagai individu yang memilki intelektualitas tinggi, baik dalam berfikir dan bertidak". Berdasarkan hal tersebut bahwa mahasiswa adalah individu yang sedang menempuh pendidikan di suatu perguruaan tinggi dan dikatagorikan memiliki intelektualitas yang tinggi, diharapkan dengan intelektualitas yang tinggi tersebut mahasiswa mempu memahami dan melaksanakan nilai-nilai yang ada dalam Pancasila, Pancasila dapat dijadikan sebagai cara berfikir dan bertindak oleh mahasiswa dalam bermasyarakat di negara ini, hal ini dikarnakan Pancasila itu sendiri merupakan sebagai dasar negara dan ideologi negara Indosesia, hal ini sebagaimana terdapat dalam Undang-Undang Dasar 1945 alinea IV yang menyatakan bahwa :

"Kemudian dari pada itu untuk dapat membentuk suatu pemerintahan negara Indonesia yang melindungi segenap bangsa Indonesia sertaseluruh tumpah darah Indonesia dan untuk memajukan kesejahteraan umum, mencerdaskan kehidupan bangsa, sertaikut dalam melaksanakan ketertiban dunia yang berdasarkan kemerdekaan, perdamaian abadi serta keadilan sosial maka disusunlah kemerdekaan kebangsaan Indonesia itu dalam suatu Undang-Undang suatu Dasar Negara Indonesia yang berbentuk dalam suatu susunan negara Republik Indonesia yang berkedaulatan rakyat dengan berdasarkan kepada Ketuhanan Yang Maha Esa, Kemanusiaan yang adil serta beradab, Persatuan Indonesia, serta Kerakyatan yang dipimpin oleh hikmat kebijaksanaan dalam permusyawaratan perwakilan, serta untuk mewujudkan suatu Keadilan sosial bagi seluruh rakyat Indonesia."

Berdasarkan hal tersebut peran pentingnya Pancasila sebagai dasar negara memilki nilainilai yang tekandung dalam setiap sila-sila Pancasila sebagai dasar negara haruslah dijadikan pedoman bagi seluruh masyarakat Indonesia, hal ini berlaku untuk mahasiswa sebagai penerus generasi bangsa kedepannya, maka melalui kurikulum yang termuat didalammya wajib melaksanakan pendidikan Pancasila di perguruan tinggi, sebagai upaya mengembangkan kepribadian mahasiswa yang sesuai dengan nilai-nilai Pancasila, dan hal ini pun berkalu di Universatas Sultan Ageng Tirtayasa, yang melaksanakan mata kuliah Pendidikan Pancasila di semester satu sebagai mata kuliah wajib universitas yang harus dikontrak mahasiswa baik mahasiswa diploma ataupun sarjana, sebagai bagian dari mata kuliah pengembangan kepribadian yang ada di Universitas Sultan Ageng Tirtayasa. Pelaksanaan mata kuliah pendidikan Pancasila diklaksanakan di semester satu disemua jurusan diploma dan sarjana dengan tujuan mahasiswa dapat mengerti, 
memahami, terampil dan melaksanakan nilainilai yang terkandung dalam setiap sila-sila Pancasila, terlebih di zaman sekarang banyaknya permasalahan di negara ini seperti radikalisme. anarkisme, terorismen dan permasalahan-permasalahan lainnya yang mengancam kedaulatan negara republik Indonesia ini, maka dari itu pentingnya mata kuliah pendidikan Pancasila ini sekaligus untuk dapat menanggulangi permasalahanpermasalahan tersebut yang ada di negara ini, pentingnya pendidikan Pancasila di perguruan tinggi sangatlah perlu diperhatikan hal ini dikarenakan pendidikan Pancasila di perguruan tinggi akan memberikan pengembangan dan penguatan terhadap diri mahasiswa dengan tujuan memiliki nilai-nilai yang pancasilais dalam diri mahasiswa tersebut. Berdasarkan latar belakang tersebut peneliti, meneliti tentang peran mata kuliah pendidikan Pancasila sebagai mata kuliah wajib umum dalam mengembangkan kepribadian mahasiswa, penelitian ini dilaksakan di Universiatas Sultan Ageng Tirtayasa, mahasiswa semester satu yang mengontrak mata kuliah Pendidikan Pancasila.

\section{METODE PENELITIAN}

Metode penelitian merupakan langkahlangkah atau tata cara untuk dapat mengungkapkan data yang objektif, penggunaan metode penelitian itu sendiri bertujuan untuk mendapatkan data penelitian berdasarkan bukti ilmiah yang kuat berdasarkan temuan hasil penelitian. hal ini sebagaimana dikemukan oleh Menurut Sugiyono (2012:5): "Metode penelitian dapat diambil kesimpulan sebagai suatu cara ilmiah yang bertujuan untuk mendapatkan data yang valid berdasakan temuan dan tujuan untuk dapat dikembangkan, dan dibuktikan berdasarkan pengetahuan yang ada, sehingga dapat dipergunakan untuk dapat memahami, memecahkan dan mengantisifasi masalah".

Berdasarkan hal tersebut metode penelitian merupakan suatu cara yang dilakukan untuk mendapatkan data yang akurat atau valid singga tingkat kebenarannya dapat dibuktikan dan dipertanggung jawabkan, dalam metode penelitan ini terdiri dari pendekatan penelitian dan metode penelitian, yang pertama pendekatan penelitian merupakan suatu cara atau langkah-langkah yang peneliti harus lakukan didasarkan atas temua penelitian yan telah peneliti lakukan, dalam pengunaan penelitian ini peneliti menggunakan pendekatan penelitian secara kualitatif, penggunaan pendekatan penelitian secara kualitatif, hal ini didasarkan atas prilaku yang ditampilkan, sebagaimana dikemukan oleh Moleong (2005:6):

"Jenis penelitian secara kualitatif adalah suatu jenis penelitian yang memfokuskan penelitian tentang apa yang dialami oleh subjek penelitian, yaitu seperti prilaku, persepsi, motivasi, dan tindakan, hal ini 
digambarkan secara deskriptif dalam suatu pemaparan kata-kata”. Berdasarkan pendapat tersebut tujuan penelitian ini yaitu peneliti memfokuskan terhadap fenomena ataupun kejadian yang dirasakan oleh subjek penelitian yang dilakukan, dalam penggunaan pendekatan penelitian secara kualitatif yang peneliti lakukan haruslah mempertimbangkan ketajaman analisis, objektivitas, sitematik dan ketepatan interperestasi dari peneliti lakukan, hal ini dikarenakan untuk mendapatkan data yang akurat sesuai dengan keadaan tempat penelitian dilakukan, selain itu alasan penggunaaan pendekatan penelitian secara kualitatif ini sendiri didasarkan atau dua hal yaitu permasalah yang peneliti teliti membutuhkan data lapangan yang bersifat aktual dan konstektual, dan alasan penggunaan pendekatan penelitan dengan menggunakan pendekatan kualitatif ini memiliki keterkaitan tentang masalah yang diteliti dengan data primer subjek penelitian yang dilakukan. Selain menggunakan pendekatan kualitatif, peneliti juga menggunakan metode. Penggunaan metode yang peneliti lakukan dengan menggunakan metode deskriptif yaitu menggambarkan tentang keadaan yang terjadi pada saat penelitian dilakukan berdasarkan data penelitian yang ada, hal ini sebagaimana dikemukan oleh Sugiyono (2015:53) pengertian deskriptif adalah :
"Penelitian deskriptif merupakan suatu jenis penelitian yang bertujuan untuk dapat mengetahui dari variabel mandiri, baik terhadap satu varibel atau lebih, dengan tidak membuat suatu perbandingan atau menghubungkan dengan variabel lainnya, variabel mandiri disini yaitu varibel yang berdiri sendiri”. Berdasarkan hal tersebut metode deskriptif dimaksudkan untuk dapat mengidentifikasi dan menjelaskan tentang aspek penelitan yang diteliti berdasarkan varibel yang ada, selain pendapat di atas pendapat Arikunto (2010:3) bahwa:

"Penelitian deskripstif adalah suatu jenis penelitian yang bermaksud untuk dapat meneliti tentang suatu keadaan, kondisi, atau suatu hal lainnya, berdasarkan hasil penelitian tersebut hasilnya dilaporkan atau dipaparkan kedalam suatu bentuk laporan penelitian, penelitian ini mengutamkan objektivitas hasil penelitian sesuai dengan temuan penelitian".

Berdasarkan hal tersebut di atas dapat diambil kesimpulan bahwa metode penelitian deskriptif bertujuan menyelidiki suatu keadaan yang hasil akhirnya dilaporkan dalam bentuk laporan penelitian, sesuai dengan data yang ada sebagai bentuk objektivitas penelitian, tujuan penggunaan pendekatan dan metode penelian disini dimaksudkan untuk dapat menjelaskan tentang bagaimana peran mata kuliah 
Pendidikan Pancasila sebagai mata kuliah wajib umum dalam mengembangkan kepribadian mahasiswa yang sesuai dengan nilai-nilai Pancasila, lokasi penelitian ini dilaksanakan di Universiatas Sultan Ageng Tirtayasa sebagai mata kuliah wajib yang harus dikontrak oleh mahasiswa itu sendiri.

\section{HASIL}

PENELITIAN

DAN

\section{PEMBAHASAN HASIL PENELITIAN}

Mata kuliah pedidikan Pancasila merupakan mata kuliah wajib umum (MKWU) dijenjang pendidikan tinggi yaitu pada tingkat diploma dan sarjana dengan bobot sebanyak 2 sks, diwajibkannya mata kuliah ini untuk dapat dilaksakan disemua perguruan tinggi hal ini dikarenakan pendidikan Pancasila memiliki peranan yang sangat penting dalam mengembangkan kepribadian mahasiswa yang sesuai dengan nilai-nilai Pancasila,

Mata kuliah pendidikan Pancasila di Universitas Sultan Ageng Tirtayasa merupakan mata kuliah wajib umum (MKWU) yang harus dilaksanakan disemua tingkat diploma dan sarjana, di Universitas Sultan Ageng sendiri mata kuliah ini dikenal dengan nama mata kuliah pengembangan kepribadian (MPK), mata kuliah pendidikan Pancasila ini memilki bobot sks sebayak 2 sks, yang dilaksanakan di semester satu atau gasal, dengan kode mata kuliah UNI 614103, dan termasuk katagori kelompok mata kuliah yang memilki kode awalan UNI, kode tersebut menunjukan bagian dari mata kuliah wajib universitas yang harus dilaksanakan ditingkat diploma dan sarjana. Pelaksanaan perkuliahan pendidikan Pancasila sebagai mata kuliah wajib pada tingkat universitas yaitu berada dibawah naungan Lembaga Pengembagan Pendidikan dan Penjamin Mutu (LP3M), melaui LP3M tersebut pelaksanaan pekuliahan pendidikan Pancasila dikoordinatori oleh koordinator pusat dan koordinator mata kuliah, pengkoordinatoran tersebut untuk dapat merencanakan, melaksanakan, dan mengevaluasi perkuliah pendidikan Pancasila agar berjalan dengan baik dan mancapai sasaran komptensi terhadap diri mahasiswa dan sekaligus untuk dapat terus meningkatkan kualitas perkuliahan mata kuliah Pendidikan Pancasila yang ada di Universitas Sultan Ageng Tirtayasa.

Pelaksanaan Mata Kuliah Pendidikan Pancasila ini sendiri mengacu pada kerangka kualifikasi nasional Indonesia (KKNI) dengan tujuan menjadikan mahasiswa yang memiliki karakter bangsa sesuai dengan nilainilai yang terkandung dalam setiap sila-sila Pancasila, peran penting mata kuliah pendidikan Pancasila yang dilaksanakan di Universitas Sultan Ageng Tirtanya tidak hanya dilaksanakan pada ranah kompetensi kognitif saja tetapai secara menyeruhuh baik dari segi kompetensi kognitif, afektif dan psikomotor, hal ini sebagaimana terdapat 
dalam rencana pembelajaran semester (RPS) yang menekankan pada capaian pembelajaran mata kuliah tersebut baik dari capaian pengetahuan, capaian sikap, dan capaian keterampilan. dan selain itu juga menekankan pada kompetensi inti matakuliah yang terdiri dari sikap spiritual, sikap sosial, Pengetahuan, Keterampilan. Kompetensi inti tersebut akan memiliki indikator sebagai bentuk dari kompetensi dasar, hal tersebut sesuai dengan esensi tujuan pendidikan nasional yang terdapat dalam UndangUndang No 20 Tahun 2003, Tujuan Dikti Undang-Undang No 12 Tahun 2012, KKNI Permendikbud No 73 Tahun 2013, dan Permendikbud No 49 Tahun 2014 tentang standar nasional pendidikan tinggi. hal ini bertujuan untuk dapat mencapai sasaran kompetensi secara menyaruruh dalam mata kuliah pendidikan Pancasila.

\section{PEMBAHASAN}

Peran mata kuliah pendidikan Pancasila sebagai mata kuliah wajib umum dalam mengembangkan kepribadian mahasiswa yang dilaksanakan di Universitas Sultan Ageng Tirtayasa mengacu pada ketentuan aturan yang berlaku, untuk dapat mencapai sasaran kompetensi sebagai mata kuliah yang memiliki peran mengembangan kepribadian mahasiswa, mata kuliah Pendidikan Kewarganegraan mempersiapkan langkahlangkah mulai dari tahap perencanaan, dalam tahap perencaaan ini dosen mempersipakan adaministrasi perkuliahan seperti kontrak perkuliahan, rencana pembelajaran semester (RPS), dan mempersipakan hal-hal yang akan dilaksanakan dalam perkuliahan, langkah selanjutnya setelah tahap perencanaan yaitu tahap pelaksanaan dalam tahap pelaksanaan ini sendiri mengacu pada langkah yang pertama yaitu tahap perencaaan, pelaksanaan tersebut diantaranya mengacu pada rencana pembelajaran semester (RPS) yang telah dibuat, dan tahap terakhir yaitu evaluasi dalam tahap ini evaluasi yang dilakukan disesuaikan dengan ketentuan yang berlaku sesuai dengan istrumen penilaian dan bobot penelian yang terdapat dalam rencana pembelajaran semester yang telah dibuat, berdasarkan hal tersebut bahwa rencana pembelajaran semester (RPS) merupakan administrasi yang menjadi acuan dalam perkulian ini untuk mendapatkan sasaran capaian pembelajaran, capaian pembelajaran tersebut menekankan pada tiga ranah capaian pembelajaran yaitu:

\section{Capaian Pengetahuan.}

Peran yang pertama dari mata kuliah Pendidikan Pancasila dalam mengembangkan kepribadian mahasiswa yang sesuai dengan nilai-nilai Pancasila yaitu melalui proses perkuliahan, dengan menekankan pada ranah pengetahuan atau kognitif, dalam pengetahuan ini sendiri mahasiswa diajarkan materi-materi yang terdapat dalam rencana 
pembelajaran semester (RPS) yaitu terdiri dari:

\section{a. Landasan Tentang Pendidikan Pancasila}

Pokok bahasan materi ini merupakan bagian dari pertemuan ke satu dan ke dua, yang membahas tentang bagaimana latar bekang pendidikan Pancasila itu sendiri, baik dari segi urgensi, sumber historis, sosiologis politik, tantangan pendidikan Pancasila, esensi dan urgensi pendidikan Pancasila. inti dalam pembehasan ini menekankan akan pentingnya pendidikan Pancasila itu sendiri dengan mengetahui apa itu pendidikan Pancasila, dan pentingnya mata kuliah pendidikan Pancasila dalam mengembangkan pribadian mahasiswa yang sesuai dengan nilai-nilai Pancasila.

\section{b. Kajian Pancasila Berdasarkan Arus}

Sejarah Bangsa Indonesia.

Materi perkuliah ini merupakan bagian dari pertemuan ke tiga dan ke empat yang menjelaskan tentang bagaimana Pancasila berdasarkan arus sejarah bangsa yang didalammya membahas tentang, urgensi, sumber historis, sosiologis, politis, dinamaka, tantangan, esensi dan urgensi, kesemuanya itu berkaitan dengan sejarah bangsa Indonesia, maksud inti dari pembahasan ini menekankan pada Pancasila yang berkaitan dengan sejarah bangsa Indonesia. dan bagaimana pentingnya Pancasila terhadap perjalanan sejarah bangsa Indonesia.

c. Pancasila Sebagai Dasar Negara
Pembahasan materi ini merupakan bagian dari pertemuan ke lima dan ke enam, dalam pembahasan ini yaitu membahas tentang kosep negara beserta tujuan dan urgensi dari dasar negara, membahas kajian bagaimana Pancasila sebagai dasar negara, membahas sumber yuridis histori sosiologis politis tentang bagaimana Pancasila sebagai dasar negara, membahas dinamika tantangan Pancasila sebagai dasar negara, dan membahas tentang esensi urgensi pentingnya Pancasila sebagai dasar negara, inti dari pembahasan ini menekankan bagaimana Pancasila sebagai dasar negara, dan urgensi Pancasila sebagai dasar negara.

d. Pancasila Merupakan Ideologi Negara. Meteri Pancasila merupakan ideologi negara adalah bagian dari pertemuan ke tujuh dan sembilan, dalam pertemuan ini membahas tentang konsep urgensi Pancasila sebagai ideologi negara, kajian tentang perlunya Pancasila sebagai ideologi negara, sumber historis sosiologis politis Pancasila sebagai ideologi negara. dinamika tantang Pancasila sebagai ideolgi negara, esensi urgensi Pancasila sebagi ideologi negara, inti dari kemuanya pembehasan ini menekankan pada bagaimana peran ideologi sebagai arahan tentang moral dalam berkhidupan di sosial masyarakat, berbangsa dan bernegara.

e. Pancasila Sebagai Sistem Filsafat

Materi ini merupakan bagian dari pertemuan kesepuluh dan kesebelas dalam pertemuan ini 
mebahas didalamnya tentang urgensi Pembahasan ini merupakan materi terakhir Pancasila sebagai sistem filsafat, yaitu terdapat dalam pertemuan ke empat diperlukannya kajian Pancasila sebagai belas dan lima belas, dalam pertemuan ini sistem filsafat, Pancasila ditinjau dari sudut pandang historis sosiologis politis sebagai sistem filsafat, bagaimana tantangan dinamika Pancasila sebagai sistem filsafat, dan esensi urgensi yang menjelaskan Pancasila sebagai sistem filsafat, inti dari meteri ini menekankan pada Pancasila sebagai genevitus objecvitus dan genevitus subjectivus kedua hal tersebut menekankan pada pendekatan tentang pengertian Pancasila sebagai filsafat, dan bagaimana pentingnya Pancasila sebagai sistem filsafat.

\section{f. Pancasila Merupakan Sistem Etika}

Pertemuan ke dua belas dan ke tiga belas membahas tentang Pancasila merupakan sistem etika yang dalam pembahasan ini terdapat materi yaitu tentang urgensi, latar belakang, sumber historis sosiologis politis, dinamika, esensi urgensi kesemuanya itu berkaiatan dengan Pancasila sebagai sistem etika, dalam pembahasan pertemuan ini menekankan pada Pancasila sebagai sistem etika bertujuan untuk mengatur tentang prilaku bermasyarakat, berbangsa dan bernegara, sekaligus sebagai rambu normatif dalam berprilakau bermasyarakat, berbangsa dan bernegara.

g. Pancasila Sebagai Dasar untuk Pengembangan Ilmu. membahas di dalamnya tentang Pancasila sebagai dasar untuk mengembangkan ilmu, dalam materi ini membahas tentang alasanya kenapa Pancasila sebagai dasar pengembangan ilmu, selanjutnya membahas tentang sudut pandang secara historis sosiologi politis Pancasila sebagai dasar pembenbagan ilmu, membahas tentang dinamika dan tantangan, serta esensi dan urgensi, kesemuanya itu berkaitan dengan Pancasila sebagai dasar pengembangan ilmu, materi ini merupakan materi terakhir yang menekankan tentang bagaimana sila-sila dalam Pancasila tersebut merupakan sebagai pedoman dan pegangan dalam pengembagan ilmu pengetahun dan juga teknologi, selain itu Pancasila sebagi dasar pengembangan ilmu bagi mahasiswa itu sendiri agar menjadi pegangan atau aturan untuk pengembangan ilmu di negera Indonesia ini. Berdasarkan capaian pengetahuan di atas tersubut secara garis besar capai pengetahuan dalam mata kulian ini yaitu termasuk kompetensi inti pengetahuan, dalam kompetensi ini mahasiswa diharapkan mampu untuk dapat memahami tentag subtansi materi-materi perkuliahan pendidikan Pancasila yang terperinci dalam kompetensi dasar yaitu mahasiswa mampu mengerti, memahami, mengidentifikasi, menganalisis, megevaluasi 
tentang subtansi dari materi-materi yang diajarkan dalam mata kuliah pendidikan Pancasila ini, dari kesemuanya itu capaian pengetahuan merupakan kompetensi kognitif, diharapkan mahasiswa yang mengontrak mata kuliah Pendidikan Pancasila akan mendapatkan pengetahuan yang luas tentang Pancasila itu sendiri, pengetahuan tersebut didapatkan melalui proses perkuliahan yang dilaksanakan mulai dari pertemuan pertama sampai dengan pertemuan terakhir, inti dalam capai ini diharapkan mampu menjadikan mahasiswa yang memilki pengetahuan tentang bagaimana dasar filosofis, sosiologis dan yuridis pelakasaan pendidikan Pancasila di perguruan tinggi, memilki pengetahuan tentang bagaimana perjalanan Pancasila dalam arus sejarah bangsa, memilki pengetahuan tentang Pancasila sebagai dasar negara, memilki pengetahuan tentang Pancasila sebagai ideologi negara, mengetahui pengetahuan tentang Pancasila sebagai sistem filsafat, mengetahui pengetahuan tentang Pancasila sebagai sistem etika, dan memiliki pengetahuan tentang Pancasila sebagai dasar pengembangan ilmu, hal ini merupakan langkah petama dalam mengembangakan kpribadian mahasiswa yaitu melalui capaian pengetahuan atau kognitif.

\section{Capaian Keterampilan}

Langkah selanjutnya setelah capaian pengetahuan adalah capaian keterampilan, dalam capaian ini proses perkuliahan bukan hanya sebatas transfer pengetahuan dari dosen terhadap mahasiswa tetapi mahasiswa dituntut untuk dapat kreatif dalam proses perkuliahan ini sebagai bentuk dari pendekatan student centred learnig, dengan pendekatan tersebut mahasiswa dapat menerapakan atau memaksimalkan keterampilan dalam proses perkulaihan pendidikan Pancasila. selain itu juga proses pembelajaran atau perkuliahan yang dilakaukan menekankan pada metode scientific approach hal ini bertujuan agar mahasiswa dapat menerapkan atau mengimplementasikan keilmuan yang mereka miliki dalam menghadapi suatu permasalahan. Berdasarkan hal tersebut di atas perkuliah pendidikan Pancasila menggunakan beberapa cara atau metode untuk dapat menerapkan capaian keterampilan yaitu melalui:

a. Metode Presentasi

Mode presentasi dalam proses perkuliahan Pendidikan Pancasila merupakan suatu kegiatan berbicara tentang suatu topik bahasan yang dilakukan pemeteri di depan umum dengan tujuan menjelaskan suatu topik bahasan tersebut, pelaksanaan presentasi yang dilakukan di mata kuliah pendidikan Pancasila ini sendiri menekankan pada pendekatan perkuliahan yang berbasis 
student centred learnig, presentasi ini bertujuan untuk dapat menggali potensi pengetahuan dan keterampilan mahasiswa dalam mata kuliah Pendidikan Pancasila yaitu melalui penyampaian materi perkuliahan di depan kelas sesuai dengan meteri yang di berikan oleh dosen.

b. Metode Studi Kasus

Metode studi kasus dalam perkuliahan Pendidikan Pancasila merupakan bagian dari student centred learning, dalam metode ini mahasiswa dituntut berperan aktif dalam mengambil suatu keputusan, selain itu metode pembelajaran atau perkuliahan ini menekankan pada keterampilan mahasiswa dalam menganalisa suatu kasus atau permasalahan dengan tujuan dapat memecahkan masalah tersebut yang disesuaikan dengan materi perkuliahan yang diajarkan sekaligus melatih daya analisis mahasiswa terhadap suatu permasalahan.

c. Metode Diskusi

Metode diskusi adalah suatu metode atau cara yang dilakukan oleh dosen terhadap mahasiswa dengan cara membagi kelompok dan diberikan suatu topik permasalahan, yang harus diselesaikan, penggunaan metode diskusi ini bertujuan untuk menjadikan pembelajaran berdemokrasi bagi mahasiswa itu sendiri yaitu dengan cara menghargai pendapat sesama mahasiswa tentang topik yang sedang dibahas untuk mendapatkan kesimpulan bersama yang disepakati.

\section{d. Metode Debat}

Metode debat merupakan suatu kegiatan menampilkan argumentasi masing-masing baik dua orang atau lebih, dalam penggunaan metode debat ini dilakuan dengan cara mahasiswa dibagi atas beberapa kelompok, didalam kelompok yang telah dibagi tersebut dilakukan metode debat tersebut, dengan tujuan mengambil keputusan atau kesimpulan tentang topik yang diperdebatkan.

e. Metode Pembelajaran Observasi Lapangan Metode pembelajaran ini merupakan suatu cara untuk mengumpulkan data dengan cara melakukan pengamatan atau mengumpulkan data di lapangan secara sistematis, dalam metode ini mahasiswa diberikan tugas kelompok untuk melakukan observasi lapangan untuk mengetahui lebih jauh tentang materi yang diajarkan di perkuliahan pendidikan Pancasila.

Berdasarkan metode-metode yang diterapkan dalam mata kuliah pendidikan Pancasila tersebut bertujuan sebagai tindak lanjut dari capaian pengetahuan yaitu untuk dapat menerapkan capaian keterampilan, inti dari capaian keterampilan ini secara garis beasar termasuk dalam katagori kompetensi inti dan kompetensi dasar yaitu diharapkan mahasiwa mampu untuk dapat menganalisa, mengolah, menalar, menyajikan, dan mampu bertindak efektif dan efisien dalam hal yang berkaitan dengan mata kuliah pendidikan Pancasila sendiri daharapkan mampu menjadikan 
mahasiswa yang memilki keterampilan dalam menerapkan pengetahuan yang telah didapat yaitu melalui daya pemikiran yang logis, keritis, inovatif, terukur, mandiri, dan bermutu, selain itu dalam capaian keerampilan ini diharapkan mahasiswa memilki keterampilan dalam menemukan pemecahan suatu masalah yang berkaitan dengan subtansi materi perkuliahan pendidikan Pancasila.

\section{Capaian Sikap}

Capaian sikap merupakan suatu capaian yang harus dapat diimplementasikan oleh mahasiswa sebagai bentuk sasaran kompetensi yang menyeluruh bukan hanya sebatas pada capaian pengetahuan dan keterampilan saja. dalam capaian sikap matakuliah pendidikan Pancasila disesuaikan dengan nilai-nilai yang terdapat dalam sila sila pancasila yaitu:

a. Capain sikap di Sila Kesatu

Dalam capai sikap atau kepribadian yang pertama melalui pendidikan Pancasila ini yaitu mampu menjadikan mahasiswa yang bertakwa kepada tuhan yang mahasa esa sebagai implentasi nilai Pancasila yang pertama, dalam hal ini peran pendidikan Pancasila untuk dapat mengembangkan kepribadian mahasiwa yang memilki nilia religius yaitu melalui materi-materi yang memiliki subtansi keterkaitan dengan nilainilai religius atau keagaman, mahasiswa harus dapat mengimplementasikan sila pertama dan sekaligus memilki rasa toleransis antar umat beragama, di Universitas Sultan Angeng Tirtayasa mahasiswanya sendiri terdiri dari berbagai penganut agama yang berbeda beda, tetapi tidak menjadikan perbedaan tersebut sebagai penghalang untuk saling beroleransis antar umat beragama, hal tersebut merupakan bentuk pengamalan dari menjalankan nilainilai agama dan bertoleransi antar umat beragama, hal tersebut merupakan suatu capaian sikap disila ke satu .

b. Capaian sikap di Sila Kedua

Setelah peran dari capai sikap yang pertama selanjutnya diharapkan menjadikan mahasiswa yang mampu menjungjung tinggi nilai kemanusian yang bermoral dan beretika, sebagai implementasi dari sila yang kedua, dalam hal ini mahasiswa dituntut untuk mengimplementasikan bagaimana menjadi mahasiswa yang memilki moral dan etika hal ini tercermin dari perilaku mahasiswa baik ketika proses perkuliahan maupun di luar proses perkuliahan, sikap tersebut dapat terlihat dari tutur kata dan perbuatan yang sopan dalam berinteraksi baik sesama mahasiwa ataupun terhadap dosen.

c. Capaian sikap di Sila Ketiga

Capaian sikap selanjutnya yaitu mampu menjadikan mahasiwa yang memilki rasa bangga dan cinta tanah air, sekaligus memiliki nasionlisme, dan memilki tanggung jawab sebagai cerminan warga negara yang 
baik, hal ini sebagai bentuk implementasi dari sila yang ketiga, keperibadian ini terlihat dari sikap mahasiwa yang menunjukan kepedulian, kesetian, dan penghargaan yang tinggi terhadap bangsa dan negara, terutama ketika negara dan bangsa ini menghadapi suatu masalah.

\section{d. Capaian sikap di Sila Keempat}

Setelah capaian sikap di atas selanjutnya untuk menjadikan mahasiswa yang memilki rasa kepekaan sosial dalam ruang lingkup masyarakat sebagai bentuk dari implementasi sila ke empat, hal ini terlihat dari kepedulian sosial yang tercermin dari bagaimana mahasiwa memiliki peranan dalam menjalankan tri dharma perguruan tinggi dangan cara melakukan pengabdian kepada masyarakat, dengan cara memberikan kontribusi yang dapat diberikan baik moril ataupun materil, dan yang lebih penting dapat membirikan pengetahuan atau edukasi sebagai implentasi dari keilmuan yang didapatkan dari mata kuliah pendidikan Pancasila.

\section{e. Capaian Sikap di Sila Kelima}

Capain sikap yang terakhir yaitu diharapkan mampu menjadikan mahasiswa yang memiliki kepribadian yang taat akan hukum sebagai bentuk dari karakter tanggung jawab, dan dapat bersikap adil, hal ini sebagai bentuk implentasi sila ke lima, keperibadian ini dapat terlihat dari sikap yang ditampilkan dalam baik di ruang lingkup universitas ataupun diluar ruang lingkup universitas, dalam ruang lingkup universitas sendiri hal ini terlihat dari mahasiwa yang mampu menjalankan ketentuan ataura yang berlaku di universitas, dan diluar ruang lingkup universitas mahasiwa mampu menjalankan atauran Undang-Undang yang berlaku di negara ini.

Berdasarkan indikator capaian sikap di atas secara garis besar capain sikap dalam mata kuliah pendidikan Pancasila dibagi atas dua kompetensi inti yaitu sikap spiritual dan sikap dan sikap sosial, sikap spriritual, sebagai kompensi inti yang dimaksudkan disini yaitu mahasiswa dapat mengamalkan ajaran agamanya masing-masing. yaitu yang tercermin dari perilaku yang ditampilkan dari kompetensi dasar yaitu mampu menjadi mahasiswa yang bersyukur sebagai cerminan nilai agama yaitu melalu sikap toleransi, sikap taat dalam menjalankan ajaran agama dalam konteks ketentuan yang berlaku di negara Indonesia. selanjutnya yaitu sikap sosial kompetensi inti ini merupakan prilaku yang ditampilkan mahasiwa sesuai dengan nilai-nilai Pancasila, nilai-nilai tersbut tercermin dari kompetensi dasar yaitu melaksnakan nilai-nilai Pancasila seperti menampilkan sikap yang jujur, disiplin, tanggungjawab, santun, toleran, cinta damai, dan memiliki keingin berkontribusi atau dapat memberikan sumbangsih terhadap negara Indonesia. diharapkan melalui capaian 
sikap pendidikan Pancasila sebagai mata kuliah pengembangan kepribadian, mampu menjadikan mahasiswa memiliki kepribadian yang sesuai dengan nilai-nilai Pancasila.

\section{SIMPULAN}

Berdasarkan penilitian yang peniliti lakukan dapat diambil kesimpulan bahwa peran mata kuliah pendidikan Pancasila sebagai mata kuliah wajib umum dalam mengembangkan kepribadian mahasiswa yang sesuai dengan nilai-nilai Pancasila sudah berjalan dengan baik, hal ini dikarenakan dalam pelaksanaannya mengedepankan kualitas perkuliahan, untuk dapat mencapai kualitas perkuliahan tersebut dilakukan dengan tiga cara yaitu tahap perencanaan, tahap pelaksaan, dan tahap evaluasi, kesemuanya itu bertujuan untuk mencapai capaian pembelajaran atau perkuliahan, capaiancapaian tersebut yaitu capaian pengetahuan, capaian keterampilan dan capaian sikap, capaian pengetahuan merupakan suatu sasaran yang ingin dicapai dalam ranah kompetensi kognitif, dimana dalam kompetensi ini mahasiswa diajarkan meterimateri yang terdapat dalam rencana pembelajaran semester (RPS), dengan tujuan mahasiswa dapat mengetahui dan memahami tentang Pancasila itu sendiri, capaian selanjutnya yaitu capaian keterampilan dalam capai keterampilan ini dimana mahasiswa dituntut untuk dapat terampil sebagai tindak lanjut dari capaian pengetahuan, dalam capaian ini dilakukan dengan proses perkuliahan yang berpusat di mahasiswa atau bagain dari student centred learning, dalam perkuliahan ini mahasiswa dilatih untuk dapat terampil mengimplementasikan pengetahuan yang telah didapatnya, keterampilan itu diterapkan dengan metodemetode dalam perkuliahan metode-metode tersebut yaitu metode presntasi, metode studi kasus, metode diskusi, metode debat, metode observasi lapangan, dengan metode-metode tersebut diterapkan dalam proses perkuliahan bertujuan untuk dapat mencapai capaian keterampilan dalam diri mahasiswa. Capaian selanjutnya yang menjadi capaian akhir dalam mata kuliah pendidikan Pancasila ini yaitu capaian sikap, capaian ini merupakan sebagai bentuk implementasi dari kedua capaian sebelumnya yaitu capaian pengetahuan dan keterampilan, dalama capaian sikap ini, mahasiswa dituntut untuk dapat mengimplementasikan capaian sikap yang sesuai dengan nilai-nilai yang terdapat dalam setiap sila-sila Pancasila, capaian sikap tersebut dapat terlihat dari prilaku yang ditampilkan oleh mahasiswa itu sendiri seperti memilki sikap religius atau taat dalam menjalankan agama yang dianutnya masingmasing, dan sekaligus memiliki sikap saling menghormati atau bertoleransi antar umat beragama hal tersebut sebagai cerminan darai sila yang pertama, capaian sikap selanjutnya 
terlihat dari prilaku yang sopan dalam bertutur kata dan perbuatan, prilaku tersebut dapat terlihat ketika berinteraksi antar sesama mahasiswa maupun dengan dosen ataupun dengan seluruh civitas akademika laiannya, hal ini menunjukan sebagai capaian pembelajaran sikap yang sesuai dengan sila kedua Pancasila, capaia sikap lainnya yaitu seprti terlihat dari perilaku yang ditampilkan mahasiswa seperti menunjukan kepedulian, kesetian, dan penghargaan yang tinggi terhadap bangsa dan negara, terutama ketika negara dan bangsa ini menghadapi suatu masalah, hal ini menunjukan sebagai capaian sikap yang sesuai dengan sila ketiga Pancasila. Capaian sikap yang keempat yaitu terlihat dari prilaku yang ditampilkan mahasiswa seperti terlihat dari kepedulian sosial yang tercermin dari bagaimana mahasiswa memilki peranan dalam menjalankan tri dharma perguruan tinggi dangan cara melakukan pengabdian kepada masyarakat, dengan cara memberikan kontribusi yang dapat diberikan baik moril ataupun materil, dan yang lebih penting dapat memberikan pengetahuan atau edukasi sebagai implentasi dari keilmuan yang didapatkan dari mata kuliah pendidikan Pancasila, hal tersebut menunjukan capaian sikap yang sesuai dengan sila ke empat dalam Pancasila. capaian sikap yang terakhir yaitu dapat terlihat dari prilaku mahasiswa yang taat akan hukum sebagai bentuk dari karakter tanggung jawab, dan dapat bersikap adil, prilaku tersebut terlihat juga dari perilaku mahasiswa yang mampu menjalankan ketentuan aturan yang berlaku di universitas, dan diluar ruang lingkup universitas mahasiswa mampu menjalankan aturan Undang-Undang yang berlaku di negara ini, hal tersebut sebagai bentuk capaian sikap yang mencerminkan prilaku yang sesuai dengan sila ke lima dalam Pancasila. berdasarkan hal tersbut bahwa pendidikan Pancasila sebagai mata kuliah wajib umum memilki peran dalam mengembangkan kepribadian mahasiswa yang sesuai dengan sila-sila Pancasila.

\section{DAFTAR PUTAKA}

\section{Buku:}

Arikunto, S. 2010. Prosedur Penelitian Suatu Pendekatan Praktik. Jakarta: Rineka Cipta.

Moleong, Lexy J. (2005). Metodologi Penelitian Kualitatif. Bandung: PT. Remaja Rosdakarya.

Siswoyo, D. d. (2007). Ilmu Pendidikan.Yogyakarta: UNY Press.

Sugiyono. 2012. Metode Penelitian Kuantitatif Kualitatif dan $R \& D$. Bandung: Alfabeta.

Sugiyono 2015. Metode Penelitian Kombinasi (Mix Methods).

Bandung: Alfabeta.

\section{Undang-Undang}




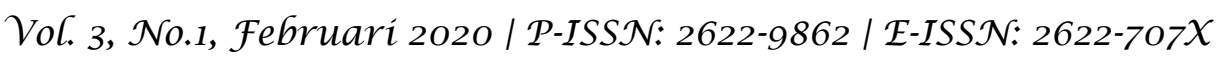

Undang-Undang Dasar 1945 alinea IV

Undang-Undang No 12 Tahun 2012

Undang-Undang No 20 Tahun 2003

Dirjen Dikti No 914/E/T/2011

Permenristekdikti No 44 tahun 2015 


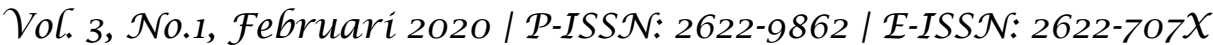

